\title{
Regenerasi Sorgum (Sorghum bicolor) melalui Kultur In Vitro
}

\author{
Regeneration of Sorghum (Sorghum bicolor) by In Vitro Culture

\section{Mega Silvia, Muhammad Hazmi*, Hidayah Murtiyaningsih, Laras S. Arum}

\author{
Program Studi Agroteknologi, Fakultas Pertanian, Universitas Muhammadiyah Jember, Jl. Karimata No. 49, Jember \\ 68121, Indonesia \\ *E-mail Penulis Korespondensi: mhazmi.hazmi@unmuhjember.ac. id
}

\begin{abstract}
Sorghum has great potential to be developed as a food source in Indonesia. This study aims to regenerate sweet sorghum in vitro, by adding coconut water and garlic powder to tissue culture. The experiment used a completely randomized design with two treatment factors, and with 2 replications. The first factor was the concentration of coconut water $(A)$, consisting of: AO $(0 \mathrm{~mL} / L)$, Al $(50 \mathrm{~mL} / \mathrm{L}), A 2(100 \mathrm{~mL} / \mathrm{L}), A 3(150 \mathrm{~mL} / \mathrm{L})$, and $A 4(200 \mathrm{~mL} / \mathrm{L})$. The second factor was the concentration of garlic powder $(B)$, consisting of : $B 0(0 \mathrm{~g} / \mathrm{L}), B 1(10 \mathrm{~g} / \mathrm{L}), B 2(20 \mathrm{~g} / \mathrm{L}), B 3(30 \mathrm{~g} / \mathrm{L})$, and $B 4(40 \mathrm{~g} / \mathrm{L})$. Data were analysis by the analysis of variance wth the F test and DMRT follow-up test at a 0,05 level. The results of the $F$ test showed that the variables of the time of shoot emergence, shoot height at the age of $3,12,15$, and 18 days after initiation (DAI) were not significantly affected by treatments $A, B$, and their interaction $(A \times B)$, also the percentage of shoot emergence in treatments $A, B$, and shoot height in treatments $B$. Variables of shoot number and shoot height at 6 DAI were affected by treatments $A, B$, and $A \times B$, also the percentage of shoot emergence in treatment $A$, and shoot height 9 DAI in treatments $A$ and B. DMRT test results showed that the A4 treatment gave the best results on shoot percentage, shoot height at 6 and 9 DAI, and treatment B2 on shoot number. The addition of $200 \mathrm{~mL} / \mathrm{L}$ coconut water increased shoot height and $20 \mathrm{~g} / \mathrm{l}$ garlic powder increased the number of shoots in this study.
\end{abstract}

Keywords: coconut water, concentration, garlic, in vitro regeneration, sorghum.

\section{ABSTRAK}

Sorgum memiliki potensi yang besar untuk dikembangkan sebagai sumber pangan di Indonesia. Penelitian ini bertujuan untuk meregenerasi sorgum manis secara in vitro, dari kultur jaringan. Percobaan menggunakan Rancangan Acak Lengkap dengan dua faktor perlakuan, dan dengan 2 ulangan. Faktor pertama adalah konsentrasi air kelapa (A), terdiri dari: A0 (0 mL/L), A1 (50 $\mathrm{mL} / \mathrm{L})$, A2 $(100 \mathrm{~mL} / \mathrm{L}), \mathrm{A} 3(150 \mathrm{~mL} / \mathrm{L})$, dan A4 $(200 \mathrm{~mL} / \mathrm{L})$. Faktor kedua adalah konsentrasi bubuk bawang putih (B), terdiri B0 (0 $\mathrm{g} / \mathrm{L}), \mathrm{B} 1(10 \mathrm{~g} / \mathrm{L}), \mathrm{B} 2(20 \mathrm{~g} / \mathrm{L}), \mathrm{B} 3(30 \mathrm{~g} / \mathrm{L})$, dan B4 (40 g/L). Data dianalisis dengan analisis ragan dengan uji F dan uji lanjut DMRT pada taraf 0,05. Hasil uji F menunjukkan bahwa variabel saat munculnya tunas, tinggi tunas pada umur 3, 12, 15, dan 18 hari setelah inisiasi (HSI) tidak nyata dipengaruhi oleh perlakuan $\mathrm{A}, \mathrm{B}$, maupun interaksinya $(\mathrm{A} \times \mathrm{B})$, demikian juga persentase munculnya tunas pada perlakuan A, B, serta tinggi tunas pada perlakuan B. Variabel-variabel jumlah tunas, tinggi tunas 6 HSI dipengaruh secara nyata oleh perlakuan $\mathrm{A}, \mathrm{B}$, maupun $\mathrm{A} \times \mathrm{B}$, demikian juga persentase munculnya tunas pada perlakuan $\mathrm{A}$, serta tinggi tunas 9 HSI pada perlakuan A dan B. Hasil uji DMRT menunjukkan bahwa perlakuan A4 memberikan hasil terbaik pada persentase tunas, tinggi tunas 6 dan 9 HSI, serta faktor B2 pada jumlah tunas. Penambahan air kelapa $200 \mathrm{~mL} / \mathrm{L}$ meningkatkan tinggi tunas dan $20 \mathrm{~g} / \mathrm{L}$ bubuk bawang putih meningkatkan jumlah tunas pada penelitian ini.

Kata kunci: air kelapa, bawang putih, konsentrasi, regenerasi in vitro, sorgum

\section{PENDAHULUAN}

Sorgum (Sorghum bicolor L.) merupakan salah satu tanaman serealia penting yang potensial untuk dikembangkan, karena memiliki banyak manfaat. Data statistik menunjukkan rata-rata produktivitas sorgum dunia pada tahun 2017 sebesar 26.617,5135 hg per ha atau 2,7 ton per ha dengan total produksi di dunia mencapai 60 juta ton (FAO-STAT, 2017). Hal ini menunjukkan bahwa sorgum merupakan salah satu sumber pangan yang patut dikembangkan di Indonesia. Sorgum memiliki berbagai potensi dan pemanfaatan, seperti sebagai sumber pangan fungsional, bahan baku industri dan juga pakan ternak. Semua bagian tanaman sorgum dapat dimanfaatkan, sebagai pakan, patinya dapat diolah menjadi tepung; batangnya dapat diolah dan menghasilkan nira untuk gula. Menurut Althwab et al. (2015), dalam setiap $100 \mathrm{~g}$ biji sorgum terkandung berbagai macam nilai gizi, seperti pati, serat, protein, lemak, kalsium, magnesium, kalium, dan fosfor. Akan tetapi, penggunaannya sebagai bahan pangan maupun industri masih terbatas, bahkan mengalami penurunan (Suarni, 2016). Melihat potensi tersebut tanaman, sorgum ini masih belum mendapat cukup perhatian untuk dikembangkan, meskipun secara ekonomis sangat menjanjikan. 
Pengembangan sorgum di Indonesia belum optimum karena berbagai masalah, seperti kurang tersedianya benih unggul dari varietas yang disenangi petani (Susilowati et al., 2013; Siantar, 2019). Varietas Sorgum hasil pemuliaan konvensional dapat ditingkatkan potensi produksinya melalui pendekatan molekuler yang mengarah ke rekayasa genetika. Menurut Damayanti et al. (2016), transformasi genetik akan berhasil dan bermanfaat apabila sudah diperoleh sistem regenerasi tanaman secara kultur in vitro. Dalam pelaksanaannya, pemilihan eksplan merupakan langkah awal yang penting dilakukan guna menunjang keberhasilan kultur in vitro. Umumnya eksplan yang digunakan untuk kultur jaringan ialah tunas pucuk (shoot tip), tunas lateral, dan epikotil (Al-Shara et al., 2018). Menurut Wang et al. (2008) dalam Wardani et al. (2019), eksplan shoot tip merupakan eksplan yang paling baik dengan tingkat kestabilan genetik dan memiliki daya untuk tumbuh kembali lebih tinggi. Selain itu, shoot tip juga memiliki jaringan meristem yang belum terdiferensiasi.

Salah satu faktor keberhasilan induksi tunas secara in vitro adalah komposisi media, seperti adanya pengaruh zat pengatur tumbuh (ZPT). Interaksi dan keseimbangan ZPT yang diaplikasikan ke dalam media kultur dan fitohormon yang diproduksi secara endogen akan menentukan arah perkembangan eksplan (Rahmi, 2017). Pemberian ZPT pada media MS (Murashige dan Skoog, 1962), dapat berupa senyawa sintetis maupun senyawa organik, seperti air kelapa, bawang putih, dan lain-lain. Ubaidah et al. (2019), dalam penelitiannya mendapatkan bahwa pengaplikasian ZPT alami dalam air kelapa dapat meningkatkan jumlah tunas dan akar, tinggi tunas, mempercepat kemunculan tunas, serta kemunculan akar pada perbanyakan pisang raja bulu. Hal tersebut dikarenakan kandungan sitokinin dan auksin yang tedapat pada air kelapa dapat berfungsi sebagai pengganti atau membantu fungsi sitokinin pada media MS.

Bawang putih mengandung beberapa unsur karbon, seperti gula dan karbohidrat, unsur mineral, seperti kalsium, besi, magnesium, fosfor, potassium, sodium, dan zinc, serta vitamin B6, tiamin, riboflavin, dan niacin (USDA, 2016). Selain itu, bawang putih memiliki berbagai kandungan senyawa aktif berupa allisin, adenosin, ajoene, flavonoid, saponin, tuberholosida, scordinin (Kuswardhani, 2016). Senyawa scordinin memiliki peran mirip dengan hormon auksin dalam proses pertumbuhan tunas dan pertumbuhan akar (Hasnah dan Abubakar, 2007; Fitriani, 2019). Artikel ini memuat tentang regenerasi sorgum dari eksplan shoot tip dengan penambahan berbagai konsentrasi air kelapa muda dan bawang putih.

\section{BAHAN DAN METODE}

\section{Waktu dan Tempat Penelitian}

Penelitian ini dilaksanakan pada bulan Maret sampai dengan Juli 2020 di Laboratorium Bioteknologi Pertanian, Fakultas Pertanian Universitas Muhammadiyah (UM) Jember.

\section{Bahan dan Alat Penelitian}

Alat yang digunakan antara lain adalah: autoclave, oven, LAF, hot plate, microwave, botol kultur, $\mathrm{pH}$ meter, gelas beaker, gelas ukur, pinset, scalpel, gunting. Bahan tanam yang digunakan adalah shoot tips (ujung tunas) tanaman sorgum manis sebagai eksplan. Sumber eksplan diambil dari sorgum koleksi di kebun percobaan Fakultas Pertanian UM Jember yang telah berumur $40 \mathrm{HST}$. Media yang digunakan adalah media MS. Zat pengatur tumbuh yang digunakan adalah kinetin. Alkohol 70\% digunakan untuk bahan sterilisasi. Air kelapa muda dan bawang putih digunakan sebagai bahan perlakuan pada media $\mathrm{MS}$. Larutan $\mathrm{NaOH}$ dan $\mathrm{HCl}$ digunakan untuk mengatur pH media MS. Bahan-bahan lainnya meliputi: kapas, kertas tissue, aluminium dan foil.

\section{Rancangan Penelitian}

Percobaan pada penelitian ini menggunakan Rancangan Acak Lengkap (RAL) 2 faktor dan dengan 2 ulangan. Setiap perlakuan memiliki 5 taraf konsentrasi. Perlakuan konsentrasi air kelapa meliputi: A0: $0 \mathrm{~mL} / \mathrm{L}, \mathrm{A} 1: 50 \mathrm{~mL} / \mathrm{L}$, A2: $100 \mathrm{~mL} / \mathrm{L}$, A3: $150 \mathrm{~mL} / \mathrm{L}$, dan A4: $200 \mathrm{~mL} / \mathrm{L}$. Perlakuan konsentrasi bawang putih meliputi: B0: 0 g/L, B1: $10 \mathrm{~g} / \mathrm{L}$, B2: $20 \mathrm{~g} / \mathrm{L}, \mathrm{B} 3: 30 \mathrm{~g} / \mathrm{L}$, dan B4: $40 \mathrm{~g} / \mathrm{L}$. Pada perlakuan A0, diberikan ZPT sintetis berupa kinetin. Data yang diperoleh dianalisis menggunakan analisis ragam (analysis of variance, Anova) dengan uji $\mathrm{F}$ untuk mengetahui pengaruh perlakuan terhadap induksi tunas sorgum. Jika ada perbedaan nyata maka akan dilanjutkan dengan analisis Duncan Multiple Range Test (DMRT) pada taraf 0,05.

\section{Pelaksanaan Penelitian}

Bawang putih yang ditambahkan pada media MS berupa powder (bubuk). Teknik pembuatannya adalah: membersihkan kulitnya lalu dicuci bersih dan diris tipis-tipis. Kemudian bawang putih dioven dengan suhu $60^{\circ} \mathrm{C}$ sampai kering. Bawang putih kering diblender hingga menjadi powder; isaring hingga mendapatkan tekstur yang lebih halus. Powder dimasukkan ke dalam botol kaca yang tertutup rapat dan disimpan di dalam kulkas. 
Penyiapan shoot tips diawali dengan isolasi eksplan dari lahan tanaman induk. Kemudian bahan tanam dibersihkan dan disterilkan dengan cara dicuci dan direndam menggunakan larutan sabun cuci ('Sunlight'). Selanjutnya bahan tanam direndam kembali dalam larutan pemutih sintetik ('Bayclin') selama kurang lebih 10 menit lalu dibilas di bawah air mengalir. Eksplan disterilkan lagi dengan alkohol $70 \%$ kemudian dibawa ke dalam LAF. Shoot tips diambil dengan memotong bagian atas buku sampai titik tumbuh, primordia daun yang menutupi jaringan meristem tersebut dibuang menggunakan pisau scalpel dengan potongan sepanjang $\pm 3 \mathrm{~mm}$. Sebelum ditanam pada media MS, shoot tip direndam dalam larutan asam askorbat selama 1-5 jam. Media MS dengan agar-agar dan tambahan sebagai perlakuan dibuat sesuai tahap-tahap baku.

\section{Variabel Pengamatan}

Variabel pengamatan meliputi: Saat munculnya tunas pada hari setelah inisiasi (HSI), yang dihitung sejak tunas muncul pada eksplan yang ditanam di media induksi. Jumlah tunas yang terbentuk pada tiap eksplan. Persentase munculnya tunas, yang dihitung dengan rumus:

Persentase $=\left(\frac{\text { Jumlah eksplan muncul tunas }}{\text { Jumlah seluruh eksplan }} \times 100 \%\right)$.

Tinggi tunas diukur dari ujung tunas aksilar sampai ujung tunas dengan satuan milimeter (mm).

\section{HASIL DAN PEMBAHASAN}

Hasil analisis data berbagai variabel pengamatan akibat konsentrasi air kelapa dan bawang putih secara tunggal disajikan pada Tabel 1 dan interaksinya $(\mathrm{A} \times \mathrm{B})$ pada Tabel 2. Respons variabel persentase tunas pada perlakuan $\mathrm{A}$, jumlah tunas, tinggi tunas pada umur 6 HSI pada perlakuan $\mathrm{A}, \mathrm{B}$, serta $\mathrm{A} \times \mathrm{B}$, dan tinggi tunas pada 9 HSI pada perlakuan A menunjukkan adanya pengaruh nyata. Untuk variabel persentase munculnya tunas $(8-11,11 \%)$, respons eksplan yang baik adalah pada perlakuan konsentrasi air kelapa $0 \mathrm{~mL} / \mathrm{L}, 150 \mathrm{~mL} / \mathrm{L}$ dan $200 \mathrm{~mL} / \mathrm{L}$. Untuk jumlah tunas, respons terbaik adalah pada perlakuan konsentrasi air kelapa $0 \mathrm{~mL} / \mathrm{L}, 150 \mathrm{~mL} / \mathrm{L}, 200 \mathrm{~mL} / \mathrm{L}(0,04-0,07)$, konsentrasi bawang putih $0 \mathrm{~g} / \mathrm{L}$, dan $20 \mathrm{~g} / \mathrm{L}(0,06-0,07)$, serta interaksi A0B2 dengan rata-rata 0,22 . Untuk tinggi tunas pada umur 6 HSI, respons eksplan terbaik adalah pada perlakuan konsentrasi air kelapa $200 \mathrm{~mL} / \mathrm{L}(0,65 \mathrm{~mm})$, konsentrasi bawang putih $0 \mathrm{~g} / \mathrm{L}$, dan $20 \mathrm{~g} / \mathrm{L}$ dengan rentang rata-rata $0,42-0,70 \mathrm{~mm}$, serta interaksi A4B0 dengan rata-rata 1,33 mm. Untuk tinggi tunas umur $9 \mathrm{HSI}$, respons eksplan terbaik dalam mempengaruhi perpanjangan tunas adalah pada perlakuan A4 $(1,02 \mathrm{~mm})$ dan interaksi A4B0 $(2,13 \mathrm{~mm})$.

Tabel 1. Rekapitulasi rata-rata variabel pengamatan terhadap penambahan air kelapa (A) dan bawang putih (B) berbagai konsentrasi

\begin{tabular}{|c|c|c|c|c|c|c|c|c|c|}
\hline \multirow{2}{*}{ Perlakuan } & \multirow{2}{*}{$\begin{array}{c}\text { ST } \\
\text { (HSI) }\end{array}$} & \multirow{2}{*}{ JT } & \multirow{2}{*}{ PT (\%) } & \multicolumn{6}{|c|}{ Tinggi tunas $(\mathrm{mm})$} \\
\hline & & & & $3 \mathrm{HSI}$ & 6 HSI & $9 \mathrm{HSI}$ & 12 HSI & $15 \mathrm{HSI}$ & $18 \mathrm{HSI}$ \\
\hline & ns & $*$ & $*$ & $\mathrm{~ns}$ & $*$ & $*$ & ns & $\mathrm{ns}$ & ns \\
\hline $\mathrm{A} 0$ & 9,75 & $0,07 \mathrm{a}$ & $13,33 \mathrm{a}$ & 0,04 & $0,31 \mathrm{~b}$ & $0,38 \mathrm{ab}$ & 0,38 & 0,47 & 0,0 \\
\hline A1 & - & $0,0 \mathrm{~b}$ & $0,0 \mathrm{~b}$ & 0,0 & $0,0 \mathrm{c}$ & $0,0 \mathrm{~b}$ & 0,0 & 0,0 & 0,01 \\
\hline $\mathrm{A} 2$ & - & $0,0 \mathrm{~b}$ & $0,0 \mathrm{~b}$ & 0,01 & $0,00 \mathrm{c}$ & $0,00 \mathrm{~b}$ & 0,00 & 0,00 & 0,02 \\
\hline A3 & 5,50 & $0,04 \mathrm{a}$ & $8,89 \mathrm{a}$ & 0,03 & $0,44 \mathrm{ab}$ & $0,66 \mathrm{ab}$ & 0,30 & 0,36 & 0,37 \\
\hline \multirow[t]{2}{*}{ A4 } & 8,25 & $0,04 \mathrm{a}$ & $11,11 \mathrm{a}$ & 0,30 & $0,65 \mathrm{a}$ & $1,02 \mathrm{a}$ & 0,77 & 0,48 & 0,0 \\
\hline & $\mathrm{ns}$ & $*$ & $\mathrm{~ns}$ & ns & $*$ & ns & ns & $\mathrm{ns}$ & ns \\
\hline B0 & 10,50 & $0,06 \mathrm{a}$ & 13,33 & 0,30 & $0,70 \mathrm{a}$ & 1,14 & 1,14 & 1,30 & 0,01 \\
\hline B1 & 4,50 & $0,02 \mathrm{~b}$ & 8,00 & 0,03 & $0,09 \mathrm{~b}$ & 0,13 & 0,00 & 0,0 & 0,02 \\
\hline B2 & 7,00 & $0,07 \mathrm{a}$ & 8,89 & 0,04 & $0,42 \mathrm{a}$ & 0,49 & 0,30 & 0,36 & 0,37 \\
\hline B3 & - & $0,0 \mathrm{~b}$ & 0,00 & 0,0 & $0,0 \mathrm{~b}$ & 0,0 & 0,0 & 0,0 & 0,0 \\
\hline B4 & 6,00 & $0,01 \mathrm{~b}$ & 3,56 & 0,0 & $0,19 \mathrm{~b}$ & 0,30 & 0,0 & 0,0 & 0,0 \\
\hline
\end{tabular}

Keterangan: ST: saat munculnya tunas; JT: jumlah tunas; PT: persentase munculnya tunas. ns: tidak berbeda nyata; *: berbeda nyata. Rata-rata yang diikuti huruf yang sama menunjukkan berbeda tidak nyata pada uji DMRT 0,05.

Hasil analisis setelah inisiasi eksplan memperlihatkan bahwa sebesar 5,8\% dari jumlah seluruh eksplan mampu bertahan hidup dan bertunas. Hal ini secara visual dicirikan dengan kondisi eksplan yang masih segar dan terdapat tanda kemunculan tunas (Gambar 1c). Hasil uji DMRT taraf 0,05 menunjukkan bahwa perlakuan A4 menghasilkan persentase 
munculnya tunas dan tinggi tunas umur 6 dan 9 HSI tertinggi. Pada perlakuan B0 dan interaksi A4B0 menghasilkan tinggi tunas umur 6 dan 9 HSI tertinggi. Untuk jumlah tunas, perlakuan A0, B0, dan interaksi A0B2 menghasilkan jumlah tunas terbanyak. Menurut Sivanesan dan Park (2015), optimalisasi unsur mineral, ZPT, dan suplemen organik dalam media MS dapat meningkatkan pertumbuhan dan morfogenesis eksplan serta dapat meningkatkan proliferasi sel dan organogenesis pada kultur in vitro.

Tabel 2. Rekapitulasi rata-rata variabel pengamatan terhadap inetraksi konsentrasi air kelapa dan bawang putih $(\mathrm{A} \times \mathrm{B})$

\begin{tabular}{|c|c|c|c|c|c|c|c|c|c|}
\hline \multirow{2}{*}{$\begin{array}{c}\text { Interaksi } \\
(\mathrm{A} \times \mathrm{B})\end{array}$} & \multirow{2}{*}{$\begin{array}{c}\text { ST } \\
(\mathrm{HSI})\end{array}$} & \multirow{2}{*}{ JT } & \multirow{2}{*}{ PT } & \multicolumn{6}{|c|}{ Tinggi Tunas $(\mathrm{mm})$} \\
\hline & & & & $3 \mathrm{HSI}$ & $6 \mathrm{HSI}$ & 9 HSI & $12 \mathrm{HSI}$ & $15 \mathrm{HSI}$ & $18 \mathrm{HSI}$ \\
\hline & $\mathrm{ns}$ & $*$ & ns & $\mathrm{ns}$ & $*$ & $*$ & ns & ns & Ns \\
\hline $\mathrm{A} 0 \mathrm{~B} 0$ & 10,50 & $0,11 \mathrm{bc}$ & 11,11 & 0,0 & $0,41 \mathrm{~b}$ & $0,72 \mathrm{~b}$ & 0,94 & 1,17 & 0,0 \\
\hline A0B1 & - & $0,0 \mathrm{c}$ & 0,0 & 0,0 & $0,0 \mathrm{~b}$ & $0,0 \mathrm{~b}$ & 0,0 & 0,0 & 0,0 \\
\hline $\mathrm{A} 0 \mathrm{~B} 2$ & 4,50 & $0,22 \mathrm{a}$ & 16,67 & 0,09 & $0,36 \mathrm{~b}$ & $0,24 \mathrm{~b}$ & 0,0 & 0,0 & 0,0 \\
\hline A0B3 & - & $0,0 \mathrm{c}$ & 0,0 & 0,0 & $0,0 \mathrm{~b}$ & $0,0 \mathrm{~b}$ & 0,0 & 0,0 & 0,0 \\
\hline A0B4 & - & $0,0 \mathrm{c}$ & 0,0 & 0,0 & $0,0 \mathrm{~b}$ & $0,0 \mathrm{~b}$ & 0,0 & 0,0 & 0,0 \\
\hline A1B0 & - & $0,0 \mathrm{c}$ & 0,0 & 0,0 & $0,0 \mathrm{~b}$ & $0,0 \mathrm{~b}$ & 0,0 & 0,0 & 0,0 \\
\hline A1B1 & - & $0,0 \mathrm{c}$ & 0,0 & 0,0 & $0,0 \mathrm{~b}$ & $0,0 \mathrm{~b}$ & 0,0 & 0,0 & 0,0 \\
\hline $\mathrm{A} 1 \mathrm{~B} 2$ & - & $0,0 \mathrm{c}$ & 0,0 & 0,0 & $0,0 \mathrm{~b}$ & $0,0 \mathrm{~b}$ & 0,0 & 0,0 & 0,0 \\
\hline A1B3 & - & $0,0 \mathrm{c}$ & 0,0 & 0,0 & $0,0 \mathrm{~b}$ & $0,0 \mathrm{~b}$ & 0,0 & 0,0 & 0,0 \\
\hline A1B4 & - & $0,0 \mathrm{c}$ & 0,0 & 0,0 & $0,0 \mathrm{~b}$ & $0,0 \mathrm{~b}$ & 0,0 & 0,0 & 0,0 \\
\hline $\mathrm{A} 2 \mathrm{~B} 0$ & - & $0,0 \mathrm{c}$ & 0,0 & 0,0 & $0,0 \mathrm{~b}$ & $0,0 \mathrm{~b}$ & 0,0 & 0,0 & 0,0 \\
\hline $\mathrm{A} 2 \mathrm{~B} 1$ & - & $0,0 \mathrm{c}$ & 0,0 & 0,0 & $0,0 \mathrm{~b}$ & $0,0 \mathrm{~b}$ & 0,0 & 0,0 & 0,0 \\
\hline $\mathrm{A} 2 \mathrm{~B} 2$ & - & $0,0 \mathrm{c}$ & 0,0 & 0,0 & $0,0 \mathrm{~b}$ & $0,0 \mathrm{~b}$ & 0,0 & 0,0 & 0,0 \\
\hline A2B3 & - & $0,0 \mathrm{c}$ & 0,0 & 0,0 & $0,0 \mathrm{~b}$ & $0,0 \mathrm{~b}$ & 0,0 & 0,0 & 0,0 \\
\hline $\mathrm{A} 2 \mathrm{~B} 4$ & - & $0,0 \mathrm{c}$ & 0,0 & 0,0 & $0,0 \mathrm{~b}$ & $0,0 \mathrm{~b}$ & 0,0 & 0,0 & 0,0 \\
\hline A3B0 & - & $0,0 \mathrm{c}$ & 0,0 & 0,0 & $0,0 \mathrm{~b}$ & $0,0 \mathrm{~b}$ & 0,0 & 0,0 & 0,0 \\
\hline A3B1 & 4,50 & $0,11 \mathrm{bc}$ & 11,11 & 0,07 & $0,22 \mathrm{~b}$ & $0,32 \mathrm{~b}$ & 0,0 & 0,0 & 0,0 \\
\hline A3B2 & 6,00 & $0,06 \mathrm{bc}$ & 5,56 & 0,0 & $0,40 \mathrm{~b}$ & $0,57 \mathrm{~b}$ & 0,75 & 0,89 & 0,92 \\
\hline A3B3 & - & $0,0 \mathrm{c}$ & 0,0 & 0,0 & $0,0 \mathrm{~b}$ & $0,0 \mathrm{~b}$ & 0,0 & 0,0 & 0,0 \\
\hline A3B4 & 6,00 & $0,06 \mathrm{bc}$ & 5,56 & 0,0 & $0,46 \mathrm{~b}$ & $0,76 \mathrm{~b}$ & 0,0 & 0,0 & 0,0 \\
\hline $\mathrm{A} 4 \mathrm{~B} 0$ & 5,25 & $0,17 \mathrm{ab}$ & 16,67 & 0,76 & $1,33 \mathrm{a}$ & $2,13 \mathrm{a}$ & 1,91 & 2,09 & 0,0 \\
\hline A4B1 & - & $0,0 \mathrm{c}$ & 5,56 & 0,0 & $0,0 \mathrm{~b}$ & $0,0 \mathrm{~b}$ & 0,0 & 0,0 & 0,0 \\
\hline A4B2 & 6,00 & $0,06 \mathrm{bc}$ & 5,56 & 0,0 & $0,29 \mathrm{~b}$ & $0,42 \mathrm{~b}$ & 0,0 & 0,0 & 0,0 \\
\hline A4B3 & - & $0,0 \mathrm{c}$ & 0,0 & 0,0 & $0,0 \mathrm{~b}$ & $0,0 \mathrm{~b}$ & 0,0 & 0,0 & 0,0 \\
\hline A4B4 & - & $0,0 \mathrm{c}$ & 0,0 & 0,0 & $0,0 \mathrm{~b}$ & $0,0 \mathrm{~b}$ & 0,0 & 0,0 & 0,0 \\
\hline
\end{tabular}

Keterangan: ST: saat munculnya tunas; JT: jumlah tunas; PT: persentase munculnya tunas; ns: tidak berbeda nyata; *: berbeda nyata; Rata-rata yang diikuti huruf yang sama menunjukkan berbeda tidak nyata pada uji DMRT 0,05.

Penambahan sitokinin eksogen memberikan pengaruh endogen pada tanaman dalam proses induksi tunas. Pada perlakuan A0, terdapat ZPT sintetis berupa kinetin. Diduga bahwa hal ini menyebabkan respon eksplan dalam pembelahan sel bisa terjadi dengan baik. Marlina (2010) dan Yustisia et al. (2018), mengemukakan bahwa di dalam media MS terdapat unsur makro, mikro, vitamin, dan ZPT tambahan yang cukup untuk memenuhi pertumbuhan eksplan pada kultur in vitro yang diharapkan. Selain karena faktor ZPT, cara pemotongan eksplan juga sangat mempengaruhi pembentukan tunas. Luas permukaan karena pelukaan yang lebih lebar bisa menjadi penyebab penyerapan nutrisi dan ZPT eksogen lebih optimal untuk pembelahan sel dan diferensiasi sel (Isda et al., 2020). Interaksi dan ketepatan konsentrasi aplikasi ZPT dalam mediakultur dan fitohormon yang diproduksi secara endogen akan menentukan arah perkembangan eksplan yang dikulturkan (Rahmi, 2017). 
Perlakuan air kelapa $0 \mathrm{~mL} / \mathrm{L}$ menghasilkan persentase tunas terbaik. Hal ini diduga mineral, vitamin, dan ZPT kinetin yang ditambahkan pada media MS sudah mencukupi dalam diferensiasi sel. Di dalam media MS terdapat unsur makro, mikro dan vitamin yang cukup untuk memenuhi pertumbuhan eksplan kultur jaringan (Marlina, 2010 dan Yustisia et al., 2018). Namun, adanya interaksi aktivitas oksidasi senyawa fenol pada shoot tip dan air kelapa dapat menghambat pertumbuhan tunas. Akan tetapi, air kelapa juga mengandung hormon alami sehingga, secara signifikan dapat mempengaruhi pembentukan tunas. Asmono et al. (2017), menyatakan bahwa penambahan air kelapa pada media MS dapat mempengaruhi pertumbuhan tunas. Pengaruh ini ditunjukkan dengan terhambatnya diferensiasi sel eksplan yang kemungkinan karena senyawa fenol. Selain itu, air kelapa juga dapat merangsang pertumbuhan tunas karena adanya ZPT alami yang dikandungnya. Data statistik menunjukkan A0 merupakan perlakuan terbaik, namun secara visual A4 menunjukkan hasil yang lebih baik, seperti yang dapat dilihat pada Gambar 1.

Perbedaan respon eksplan terhadap ZPT disebabkan karena kemampuan genetik eksplan yang berbeda-beda (Putriana et al., 2019). Pertumbuhan tunas ini diduga karena adanya peran hormon sitokinin dan auksin yang berfungsi untuk peningkatan ketahanan dan poliferasi tunas. ZPT yang terkandung dalam air kelapa seperti sitokinin memberikan respon pada pembentukan tunas. Royani (2019), melaporkan bahwa dengan penambahan air kelapa konsentrasi 200 $\mathrm{mL} / \mathrm{L}$ mampu memberikan jumlah tunas dan akar terbanyak pada induksi planlet anggrek Cattleya sp secara in vitro.

Tunas pada masing-masing perlakuan memiliki laju pertumbuhan yang berbeda-beda pada interval waktu yang berbeda pula pada rentang umur 3-18 HSI (Gambar 2). Pada perlakuan A0B0, tunas menggambarkan peningkatan laju pertumbuhan dari pertama munculnya tunas umur 6 HSI hingga 15 HSI dan pada umur 18 HSI tunas browning sehingga, menyebabkan kematian.
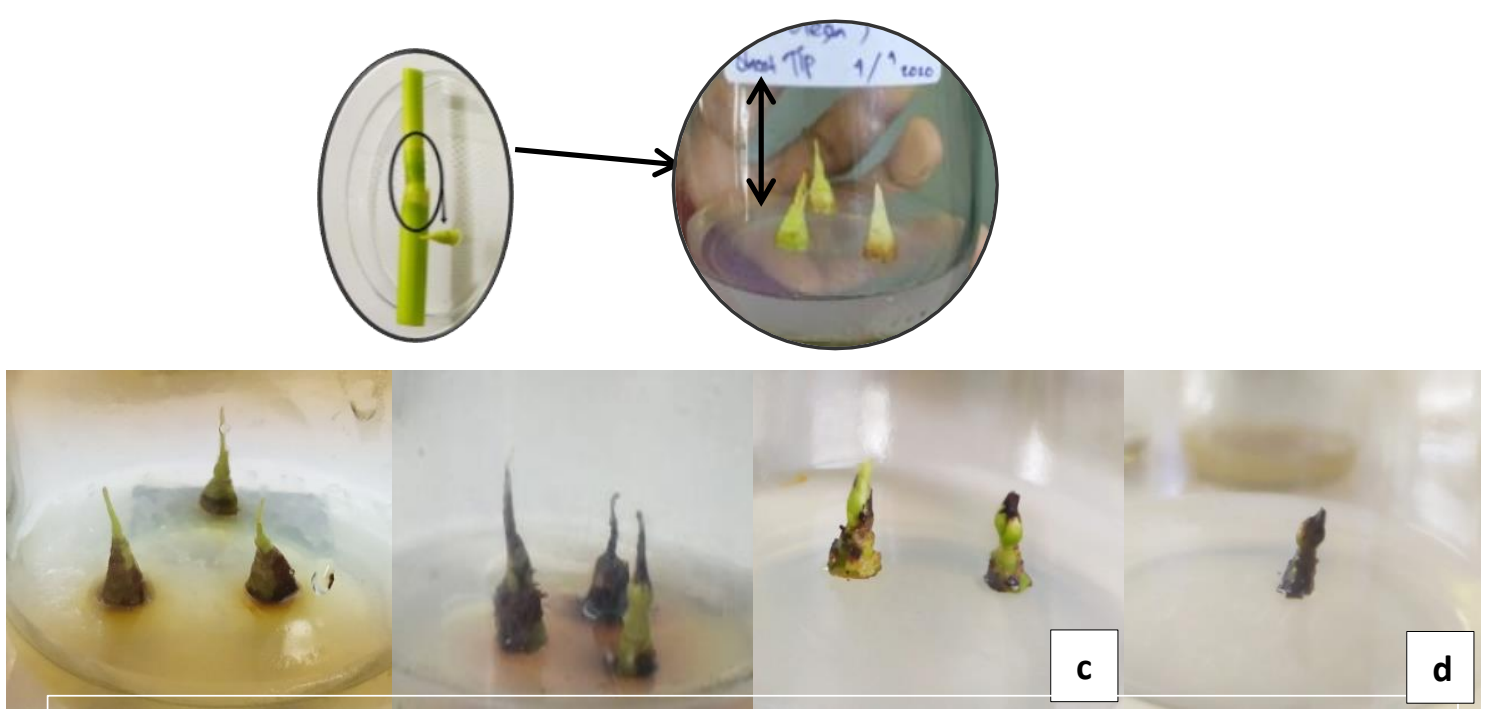

A0B0 (Air kelapa $0 \mathrm{~mL} / \mathrm{L}+$ bawang putih $0 \mathrm{~g} / \mathrm{L}$ )

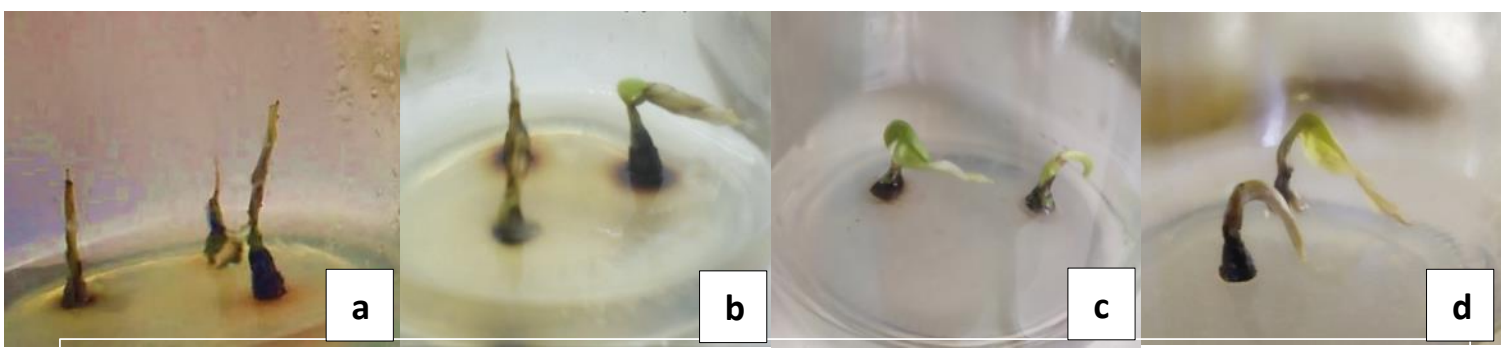

A4B0 (Air kelapa $200 \mathrm{~mL} / \mathrm{L}$ + bawang putih $0 \mathrm{~g} / \mathrm{L}$ )

Gambar 1. Pertumbuhan tunas pada eksplan shoot tips sorgum pada perlakuan A0B0 dan A4B0. a) tunas umur 3 HSI; b) tunas umur 9 HSI; c) tunas umur 12 HSI; d) tunas umur 15 HSI.

Pada perlakuan A0B2, tunas muncul pada umur 3 HSI mengalami penurunan laju pertumbuhan pada umur 9 HSI karena beberapa sampel mengalami kematian. kemudian pada umur 12 HSI seluruh tunas mati diakibatkan oleh browning atau pencoklatan. Pada perlakuan A3B1, tunas muncul pada umur 6 HSI dan mengalami peningkatan laju pertumbuhan hingga umur 18 HSI. Sedangkan pada perlakuan air kelapa konsentrasi A3B4, tunas yang muncul pada umur 6 HSI hanya mampu bertahan hidup sampai umur 9 HSI, kemudian pada umur 12 HSI, semua tunas mati karena browning. 
Pada perlakuan A4B0 tunas mulai muncul umur 3 HSI dan mengalami peningkatan laju pertumbuhan hingga umur 9 HSI. Namun pada umur 12 HSI grafik laju pertumbuhan menurun, yang disebabkan oleh kematian tunas pada salah satu sampel. Hingga pada umur 15 HSI tunas mengalami peningkatan laju pertumbuhan kembali, yang dapat dilihat dari bertambahnya ukuran tinggi tunas pada beberapa sampel. Akan tetapi, pada umur 18 HSI tunas mati dengan penyebab yang sama, seperti perlakuan-perlakuan lainnya. Pada perlakuan A4B2, tunas yang muncul pada umur 6 HSI juga mengalami peningkatan laju pertumbuhan. Namun itu hanya mampu bertahan hidup sampai umur 9 HSI, karena pada umur 12 HSI tunas mati karena browning. Diduga bahwa tingginya konsentrasi air kelapa menjadi suatu hambatan bagi pembentukan tunas, begitu pula dengan bawang putih. Adanya senyawa fenol dan tannin dalam air kelapa diduga menjadi penyebab utama terhambatnya pembelahan dan diferensiasi sel. Sehingga, hal inilah yang menyebabkan eksplan mengalami browning sampai gagal tumbuh.

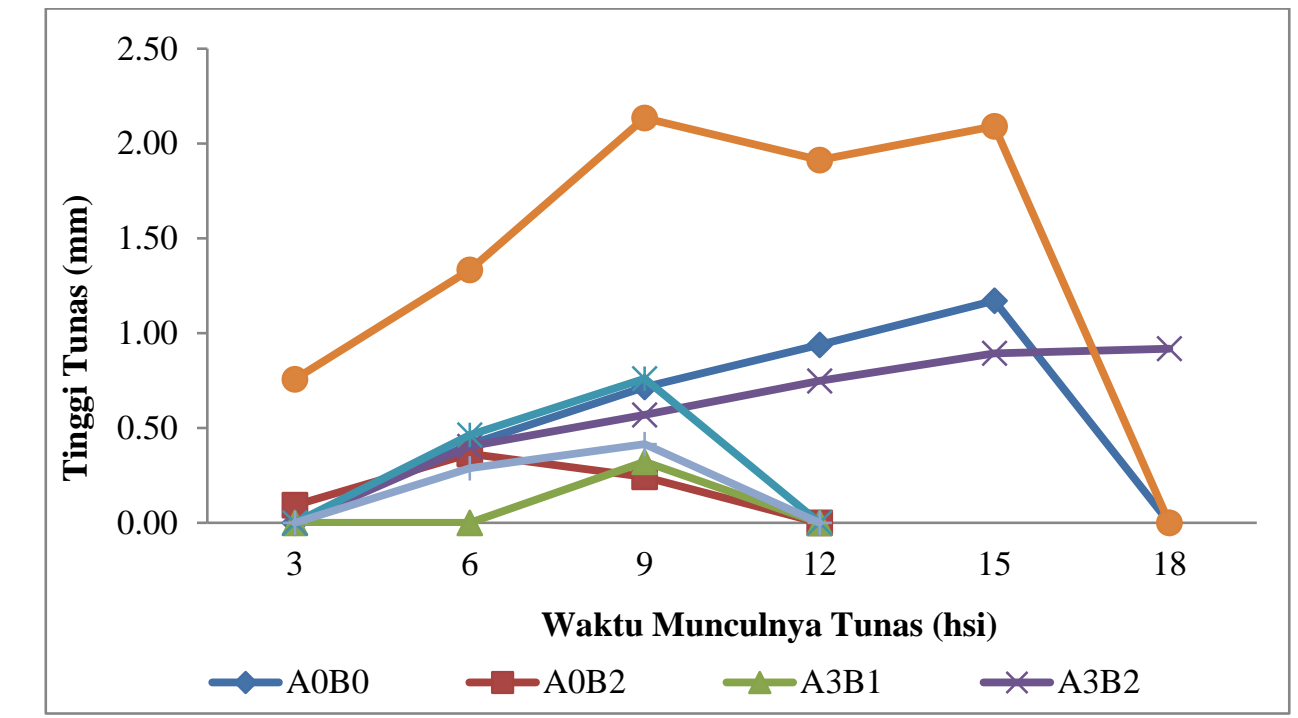

Gambar 2. Laju pertumbuhan rata-rata tinggi tunas yang dipengaruhi oleh berbagai konsentrasi air kelapa dan bawang putih pada interval waktu berbeda.

Adanya senyawa fenolik yang terdapat pada air kelapa, menjadi penghambat pembentukan tunas. Senyawa tersebut mempengaruhi keseimbangan hormon untuk memacu diferensiasi sel. Mulyanto et al. (2018), melaporkan bahwa dalam air kelapa terdapat kandungan senyawa tannin. Aktivitas senyawa tannin juga dimiliki oleh bawang putih. Berdasarkan hasil penelitian Prasonto et al. (2017), dalam bawang putih memiliki daya aktivitas antioksidan. Antioksidan yang merupakan bahan aktif dari bawang putih berupa senyawa alkaloid, flavonoid, saponin, tannin, dan fenol (Tigauw et al., 2015).

Faktor-faktor yang dapat mempengaruhi terjadinya browning menurut Wang et al. (2016), adalah musim (pengambilan eksplan), bagian eksplan yang diambil, dan juga media kultur. Sui et al. (2019) juga menjelaskan bahwa penyebab utama browning pada eksplan adalah polifenol pada tanaman, yang membentuk antrakuinon coklat karena aktivitas polifenol oksidase. Hal inilah yang dapat menyebabkan pertumbuhan terhambat hingga terjadi kematian pada eksplan. Sejalan dengan apa yang dituturkan oleh Wang et al. (2016), bahwa adanya akumulasi dan plifenol oksidase menjadi penyebab utama penghambatan pertumbuhan eksplan dan penurunan kemampuan regenerasi sel.

\section{KESIMPULAN}

Kesimpulan-kesimpulan dari penelitian ini adalah sebagai berikut:

1. Eksplan shoot tips sorgum responsif pada perlakuan konsentrasi air kelapa $200 \mathrm{~mL} / \mathrm{L}$ berdasarkan variabel persentase munculnya tunas serta tinggi tunas pada umur 6 dan 9 HSI.

2. Eksplan shoot tips sorgum responsif pada perlakuan konsentrasi bawang putih $20 \mathrm{~g} / \mathrm{L}$ berdasarkan variabel jumlah tunas dan $0 \mathrm{~mL} / \mathrm{Ldalam}$ variabel tinggi tunaspada umur $6 \mathrm{HSI}$.

3. Eksplan sorgum responsif pada interaksi perlakuan konsentrasi air kelapa $0 \mathrm{~mL} / \mathrm{L}$ dan bawang putih $20 \mathrm{~g} / \mathrm{L}$ berdasarkan variabel jumlah tunas serta $200 \mathrm{~mL} / \mathrm{L}$ dan bawang putih $0 \mathrm{~mL} / \mathrm{L}$ dalam variabel tinggi tunas umur 6 dan 9 HSI.

4. Untuk mendapatkan jumlah tunas yang baik dapat ditambahkan bubuk bawang putih $20 \mathrm{~g} / \mathrm{L}$, dan $200 \mathrm{~mL} / \mathrm{L}$ air kelapa untuk tinggi tunas. 


\section{UCAPAN TERIMA KASIH}

Penulis mengucapkan terima kasih kepada Tim pelaksana Main Research, Laboratorium Bioteknologi Pertanian dan LPPM Universitas Muhammadiyah Jember atas atas fasilitas dan pendanaan penelitiannya.

\section{DAFTAR PUSTAKA}

Al-Shara, B., R.M. Taha, and K. Rashid. 2018. Biotechnological methods and limitations of micropropagation in papaya (Carica papaya L.) production: a review. The Journal of Animal and Plant Sciences 28: 1208-1226.

Althwab, S., T.P. Carr, C.L. Weller, I.M. Dweikat, and V. Schlegel. 2015. Advances in grain sorghum and its coproducts as a human health promoting dietary system. Food Research International 77: 349-359. DOI: http://dx.doi.org/10.1016/j.foodres.2015.08.011.

Asmono, S.L., V.K. Sari, dan R. Wardana. 2017. Respons pertumbuhan tunas mikro stevia (Stevia Rebaudiana Bertoni) cecara in vitro pada beberapa jenis sitokinin dan konsentrasi air kelapa. Agrin, Jurnal Penelitian Pertanian 21(2): 146-154. DOI: http://dx.doi.org/10.20884/1.agrin.2017.21.2.395.

Damayanti, D., S. Sudarsono, I. Mariska, dan M. Herman, 2016. Regenerasi pepaya melalui kultur in vitro. Jurnal AgroBiogen 3(2): 49-54. DOI: http://dx.doi.org/10.21082/jbio.v3n2.2007.p49-54.

FAO-STAT. 2017. Sorghum Production Quantity. Food and Agriculture Organization of the United Nations Statistics. http://www.fao.org/faostat/en/\#data/QC.

Fitriani, N. 2019. Pengaruh Ekstrak Bawang Merah dan Bawang Putih terhadap Pertumbuhan Akar Stek Batang Mawar (Rosa damascena Mill). Skripsi. UIN Sunan Ampel, Surabaya.

Hasnah, H. dan M.I. Abubakar. Efektivitas ekstrak umbi bawang putih (Allium sativum L.) untuk mengendalikan hama Crocidolonia pavonana F. pada tanaman sawi. Agrista 11(2): 108-113.

Isda, M.N., Elvianis, dan S. Fatonah. 2020. Induksi tunas pada beberapa tipe pemotongan eksplan bonggol Pisang Udang (Musa Acuminata Colla) secara in vitro. Jurnal Biologi Universitas Andalas 8(1): 20-28. DOI: http://dx.doi.org/10.25077/jbioua.8.1.20-28.2020.

Kuswardhani, D.S. 2016. Sehat Tanpa Obat dengan Bawang Mera dan Bawang Putih. Yogyakarta: Rapha Publishing. ISBN: 9789792951073.

Marlina. 2010. Pengaruh Media MS Terhadap Pertumbuhan Planlet. Pustaka Baru Press, Malang.

Mulyanto, A., I. Mujahid, dan T.U. Khasanah. 2018. Kemampuan air kelapa muda sebagai antimikroba terhadap bakteri Escherichia coli penyebab diare. Jurnal Bio-site, Biologi dan Sains Terapan 4(1): 18-24. DOI: https://doi.org/10.22437/bs.v4i1.4963

Murashige, T. and F. Skoog. 1962. A revised medium for rapid growth and bio assays with tobacco tissue cultures. Physiologia Plantarum 15(3): 473-497.

Prasonto, D., E. Riyanti, dan M. Gartika. 2017. Uji Aktivitas Antioksidan Ekstrak Bawang Putih (Allium sativum). Odonto Dental Journal 4(2): 122-128. DOI: http://dx.doi.org/10.30659/odj.4.2.122-128

Putriana, Gusmiaty, M. Restu, Musriati, dan N. Aida. 2019. Respon kinetin dan tipe eksplan Jabon Merah (Antocephalus macrophyllus (Roxb.) Havil) secara in vitro. Bioma, Jurnal Biologi Makassar 4(1): 48-57. DOI: https://doi.org/10.20956/bioma.v4i1.6363.

Rahmi, A.F., A. Purwito, A. Husni, dan D. Dinarti. 2017. Embriogenesis dan desikasi embrio somatik jeruk keprok Batu 55 (Citrus reticulata Blanco.) untuk meningkatkan frekuensi perkecambahan. Jurnal Hortikultura Indonesia 8(2): 79-87.

Royani, I. 2019. Induksi planlet anggrek Cattlyea sp secara in vitro pada media Murashige-Skoog dan bahan organik. Jurnal Ilmiah Mandala Education 5(2): 1-4. DOI: http://dx.doi.org/10.36312/jime.v5i2.750.

Siantar, P.L., E. Pramono, M.S. Hadi, dan Agustiansyah. 2019. Pengaruh kombinasi varietas dalam tumpangsari sorgum-kedelai pada pertumbuhhan dan produktivitas benih sorgum dan kedelai, dan vigor daya simpan benih sorgum. Jurnal Siliwangi, Sains Teknologi 5(1): 22-39.

Sivanesan, I., dan S.W. Park. 2015. Optimizing factors affecting adventitious shoot regeneration, in vitro flowering and fruiting of Withania somnifera (L.) Dunal. Industrial Crops and Products. 76 : $323-328$. DOI: https://doi.org/10.1016/j.indcrop.2015.05.014.

Suarni, 2016. Peranan sifat fisikokimia sorgum dalam diversifikasi pangan dan industri serta prospek pengembangannya. Jurnal Penelitian dan Pengembangan Pertanian 35(3): 99-110.

Sui, L., L. Kong, X. Liu, Y. Zhang. 2020. Anti-browning in tissue culture of 'Donghong' kiwifruit. IOP Conference Series, Materials Science and Engineering 740: 012195 DOI: https://doi.org/10.1088/1757-899X/740/1/012195.

Susilowati, S.H. dan H.P. Saliem. 2013. Perdagangan sorgum di pasar dunia dan Asia serta prospek pengembangannya di Indonesia. p. 7-23. Dalam Buku Sorgum: Inovasi Teknologi dan Pengembangannya. Pusat Penelitian dan Pengembangan Tanaman Pangan, Bogor.

Tigauw, S.M.I., C.L. Salaki, dan J. Manueke. 2015. Efektivitas ekstrak bawang putih dan tembakau terhadap kutu daun (Myzus persicae Sulz.) pada tanmaan cabai (Capsicum sp.). Eugenia 21(3): 135-141. DOI: https://doi.org/10.35791/eug.21.3. 2015.9703.

Ubaidah S.N., R. Malinda, H. Widjianto, dan A. Yunus. 2019. Penambahan air kelapa dan IAA pada pertumbuhan tunas pisang Raja Bulu secara in vitro. Prosiding Seminar Nasional Fakultas Pertanian UNS 3(1): A.93-99.

USDA. 2016. National Nutrient Database for Standard Reference of Raw Garlic. United States Departement of Agriculture. https://www.ndb.nal.usda.gov/ndb/foods/show/2968.

Wang, M., F. Liao, L. Yang, D-L. Huang, L-T. Yang, and Y-R. Li. 2016. Influence factors and cell structure changes related to sugarcane stem tip browning in vitro culture. International Journal of Agriculture Innovations and Research 4 (4):767-773. ISSN (Online): 2319-1473. 
Wardani, F.F., D. Efendi, D. Dinarti, dan J.R. Witono. 2019. Perbanyakan pepaya (Carica papaya L.) 'Sukma' in vitro dari eksplan tunas pucuk sebagai respon terhadap BA dan NAA. Jurnal Agronomi Indonesia 47(2): 203-209. DOI: https://doi.org/10.24831/jai.v47i2.25115.

Yustisia, D., M. Arsyad, A. Wahid, dan J. Asri. 2018. Pengaruh pemberian ZPT alami (air kelapa) pada media MS0 terhadap pertumbuhan planlet tanaman kentang (Solanum tuberosum L.). Jurnal Agrominansia 3(2): 130-140. DOI: 10.34003/272009. 